\title{
The Economic Origins of 20th Century Decolonisation in West Africa*
}

\author{
Julius A. Agbor $\dagger^{\dagger}$ Johannes W. Fedderke $\&^{\ddagger}$ Nicola Viegi ${ }^{\S}$ \\ August 7th, 2010
}

\begin{abstract}
This paper argues that the pattern of decolonisation was a logical consequence of the nature of human capital transfers from the colonisers' to the elites of the former colonies, and this shaped the strategic interaction between these two groups. Where the educational ideology emphasized the notion of assimilation, the system generally tended to produce elites that depended highly on the coloniser for their livelihood, hence necessitating a continuation of the imperial relationship even after independence was granted. On the contrary, where the ideology emphasized the strengthening of the 'solid elements' of the countryside, the system tended to produce a bunch of elites that were quite independent of the coloniser and consequently had little to loose from a disruption of the imperial relationship at independence. The results of the model shed light into why the French decolonisation process in West Africa was generally smooth and transited from colonialism to neo-colonialism whereas British decolonisations in West Africa were generally antagonistic, culminating in complete independence from England. The paper contributes to existing knowledge by providing an alternative explanation of 20th century decolonisation, archored on human capital transfers, an approach which unifies both the Eurocentric and Afrocentric perspectives.

Keywords: Decolonisation, Human Capital Transfers, Eurocentrism, Afrocentrism, West Africa. JEL Codes: C70, F54, I20, N17.
\end{abstract}

${ }^{*}$ We would like to thank participants at the following seminars - November 2009 Workshop of the Economic History Society of Southern Africa, and August 2009 Macro Workshop Seminar Series at the School of Economics of the University of Cape Town, for helpful comments. Financial support from the A.W. Mellon Foundation Fellowship and the African Economic Research Consortium is gratefully acknowledged. The standard disclaimer applies.

${ }^{\dagger}$ University of Cape Town, juliusagbor2002@yahoo.fr, +27822274878

${ }^{\ddagger}$ Penn State University \& ERSA, jwf15@sia.psu.edu

$\S$ University of Pretoria \& ERSA, nicola.viegi@up.ac.za 


\section{Introduction}

The pattern in which decolonisation took place in sub-saharan Africa was quite intriguing. While the French peacefully withdrew from their sub-Saharan African (henceforth abbreviated as SSA) empires in one day, ${ }^{1}$ paving the way for a transition from colonialism to neo-colonialism, the British were unable to decolonise smoothly, and the transition to independence in British SSA colonies was generally antagonistic, often culminating in complete independence from England. Most of the explanations of decolonisation ${ }^{2}$ emphasises long run processes of changing economic incentives for the colonisers ${ }^{3}$, the rise of new nationalist movements in the colonies and the change in balance of power in international relationships, Thorn (2000). However, these traditional reasons fail to account for the contrasting decolonisation patterns in SSA.

The objective of this paper is to attempt an explanation of why the pattern of decolonisation in the French SSA empire differed significantly from that in the British SSA empire. The paper argues that the pattern of decolonisation in SSA was a function of the nature of human capital transfers from the colonisers to the indigenous elites of the former colonies. Underpinning the nature of these human capital transfers is the colonial educational ideology. Specifically, the study models the role of human capital transfers from the colonisers to the indigenous elites of the colonies in the process of decolonisation. This approach, it is hoped, will forge a unified economic interpretation of decolonisation which might in turn, contribute to a fuller understanding of the dynamics of change that brought about twentieth century decolonisation processes.

But first a working definition of the concepts of colonisation and decolonisation is in order. The term "colonisation" in this study is understood to mean the process of creation of empires, ${ }^{4}$ whilst "decolonisation" describes the process of European withdrawal from

\footnotetext{
${ }^{1}$ Besides Guinea, which unilaterally withdrew from the French community in 1958, all French subSaharan African colonies received their political independence from Paris on the same date in 1960.

${ }^{2}$ These reasons have been regrouped into three major schools, namely, the Eurocentric, Afrocentric and Liberal explanations of decolonisation, Thorn (2000). The Eurocentric school basically argues that the colonisers themselves sought to withdraw from empires because it was no longer in their economic or political interest to continue colonial rule, while the Afrocentric view argues that the colonisers were forcefully evicted from empires by elite-led nationalist movements. The liberal view on its part, places the fulcrum of change within shifts in international relations.

${ }^{3}$ See for instance, Gartzke and Rohner (2010)

${ }^{4}$ Historians have generally distinguished colonisation from imperialism, the latter referring to the process of creation of empires and the former referring to only those parts that were actually settled in by the people of the imperialist power, Thorn (2000). Modern day historians have used the term "formal empires" to denote colonisation and "informal empires" to describe territories that were not settled in by Europeans. For simplicity, I make no distinction between either forms of empires and I will use the
} 
empires, whether they be empires of sovereign administration or of trusteeship administration. ${ }^{5}$

Because decolonisation is a profoundly complex historical process with multi-faceted determinants, it makes intellectual sense to limit this study both in time and in space. This study thus proposes to model the decolonisation processes in West Africa during the twentieth century and the focus is naturally on the British and French decolonisation processes, although the model also provides useful insight into other decolonisation processes outside the region.

A quick look at the historical data presented in Figure 1 below provides some justification for the choice of this model.

Figure 1: Historical Evidence Comparing British and French West African States

\begin{tabular}{|c|c|c|c|c|c|c|c|c|c|c|c|c|c|}
\hline \multicolumn{7}{|c|}{ French West African States } & \multicolumn{7}{|c|}{ British West African States } \\
\hline & INDEP & couPs $^{\mathrm{a}}$ & TMIS $^{b}$ & PRISON $^{c}$ & INC DIST ${ }^{d}$ & REPRESS ${ }^{e}$ & & INDEP & coups $^{\mathrm{a}}$ & TMIS $^{\mathrm{b}}$ & PRISON $^{c}$ & INC DIST $^{d}$ & REPRESS ${ }^{e}$ \\
\hline Burkina Faso & 1960 & 13 & 39 & & 362 & & Gambia & 1965 & 3 & 11 & & & 0 \\
\hline Benin & 1960 & 15 & 45 & & 9.39 & 0 & Ghana & 1957 & 22 & 54 & 0.03 & 38.2 & 21 \\
\hline Central A. Rep & 1960 & 10 & 32 & & 102.9 & 1 & Nigeria & 1960 & 12 & 40 & & 30.6 & 15 \\
\hline Chad & 1960 & 5 & 13 & & 9.6 & 1 & Sierra Leone & 1961 & 16 & 48 & & 14.9 & 3 \\
\hline Congo Rep & 1960 & 10 & 26 & & & 9 & & & & & & & \\
\hline Gabon & 1960 & 4 & 6 & & & 0 & & & & & & & \\
\hline Guinea & 1958 & 12 & 22 & & 131.6 & 0 & & & & & & & \\
\hline Ivory Coast & 1960 & 6 & 14 & 0.07 & 14.5 & 1 & & & & & & & \\
\hline Mali & 1960 & 7 & 15 & & 348.2 & 9 & & & & & & & \\
\hline Mauritania & 1960 & 10 & 24 & & 705.1 & 7 & & & & & & & \\
\hline Niger & 1960 & 6 & 22 & & 47.4 & 1 & & & & & & & \\
\hline Senegal & 1960 & 1 & 3 & & 39.8 & 1 & & & & & & & \\
\hline Togo & 1960 & 11 & 31 & & & 10 & & & & & & & \\
\hline Average & 1959.8 & 8.5 & 22.5 & & 177.1 & 3.3 & Average & 1960.7 & 13.2 & 38.2 & & 27.9 & 9.7 \\
\hline \multicolumn{14}{|c|}{ a: Coups include the number of plots, failed and successful coups from 1956 to 2001, McGowan (2003). } \\
\hline \multicolumn{14}{|c|}{ b: Total Military Intervention Score (TMIS) captures trends in coup behaviour during 1956-2001, McGowan (2003). } \\
\hline \multicolumn{14}{|c|}{ c: Average number of prisoners of criminal offences in 1936 as a percentage of country's population. Source: Asiwaju (2000:53) for Ivorian figures, Kay \& Stephen (1972) for Ghanaian figures. } \\
\hline \multicolumn{14}{|c|}{ d: Income distance at independence, calculated by taking the ratio of income of top $10 \%$ and bottom $10 \%$ of population, figures available rom World Income Inequality datasets } \\
\hline e: Number of case & of repressic & recorded be & een 1950 & nd year of ind & dependence & e, obtained $\mathrm{f}$ & from Alesina et al & (1992) data & & & & & \\
\hline
\end{tabular}

For instance, columns 2 and 9 of Figure 1 suggest that independence was achieved on average much faster in French West Africa than in British West Africa. Furthermore, columns 3, 4, 10 and 11 confirm that post independence French West African states witterms colonisation and imperialism interchangeably.

${ }^{5}$ In spite of the fact that the decolonisation of UN trust territories established after World War II was supposed to be predetermined and smooth, it often wasn't the case which is why we include them in this category. 
nessed less coup d'états and less military interventions, thus were generally more politically stable than their British counterparts. Also, prior to independence, British West African states witnessed more acts of repression (thus, instability) than their French counterparts as columns 7 and 14 suggest.

Columns 5 and 12 gives us the per capita number of prisoners of criminal offences in 1936 (far in the period of colonial rule) for Ivory Coast and Ghana respectively. These figures suggest that there were more politically motivated prisoners in the Ivory Coast, in comparison with Ghana. ${ }^{6}$ In addition to this evidence, several historical sources also confirm that French colonial rule was not only highly repressive but also heavy in terms of the fiscal burden. ${ }^{7}$ For instance, Crowder (1968:185), cites the "code d'indigénat" as clear evidence of the repressiveness of French colonial rule. The code, which applied to the African masses only and in existence from the early 20th century, envisaged about fifty punishable offences.

Besides these offences, under the code, each adult African was liable to an annual tax in labour equivalent to 12 days labour, redeemable at 1-3 Franc CFA a day. Due to the repressiveness of French colonial rule, Asiwaju (2000) contends that, there were massive exodus of peoples from Ivory Coast and the neighbouring French colonies into Ghana during the 1930s.

Finally, columns 6 and 13 suggests that the income distance between the elites and the masses were furthest in former French colonies in comparison with former British colonies, which lends some credence to the basic assumption of the model to be discussed - that Francophone West African elites were more disconnected from the masses than their Anglophone counterparts.

Table 1 below, provides evidence in support of the premise that francophone West African elites were more professionally inclined to government occupations during the period between 1947-1952. The figures show that averagely about three-quarters of francophone West African leaders represented in the territorial legislative assembly were colonial government employees. ${ }^{8}$ In other words, these elites largely depended for their livelihood on colonial government employment or patronage. In the former British colony of the

\footnotetext{
${ }^{6}$ For the years 1933, 1934 and 1935, the per capita number of prisoners in Ivory Coast was 0.05, 0.05 and 0.07, respectively, while in Ghana it was 0.03 throughout those years, Asiwaju (2000) and Kay \& Stephen (1972).

${ }^{7}$ Crowder (1968:186) contends that the idea which seemed best to the French colonial system for achieving the employment of native labour, was to impose relatively high taxes on blacks, and in default of payment they would incur a sentence of forced labour.

${ }^{8}$ The French sociologist, George Balandier, has coined the term "administrative bourgeoisies" to describe Francophone African elites.
} 
Table 1: Professional Background of Francophone West African Leaders during 1947-1952. Source: Morgenthau (1964)

\begin{tabular}{|c|c|c|c|}
\hline Country & $\begin{array}{l}\text { No. in Territorial } \\
\text { Assembly }\end{array}$ & $\begin{array}{l}\% \text { Employed by } \\
\text { Government }\end{array}$ & $\begin{array}{l}\% \text { in Liberal Pro- } \\
\text { fessions }\end{array}$ \\
\hline Ivory Coast & 27 & 78 & 15 \\
\hline Mali & 28 & 86 & 15 \\
\hline Upper Volta & 40 & 87 & 2 \\
\hline Niger & 20 & 90 & - \\
\hline Senegal & 50 & 42 & 18 \\
\hline Guinea & 16 & 75 & 25 \\
\hline
\end{tabular}

Gold Coast, in contrast, an investigation into the background of 32 active members of the pioneer nationalist movement - the National Congress of British West Africa (NCBWA) Gold Coast branch - in the 1920s, reveals that about $90 \%$ of them were employed in the liberal professions, Gifford \& Louis (1971).

The paper is organised as follows. Section 2 briefly highlights the major distinguishing features of British and French colonial education policies in West Africa and also contrasts the different perceptions and reactions of Anglophone and Francophone West African elites to post-World War II (WWII) colonisation and decolonisation discourse. Section 3 presents the model, discusses the results and the theoretical implications while section 4 summarises the core predictions of the model. Section 5 concludes.

\section{Distinguishing Aspects of British and French Colo- nial Education Practices}

Historians generally believe that the major distinguishing features between the British and French colonisation in black Africa are rooted in their divergent objectives and approaches to colonial education. Whereas French colonial education ideology emphasized the notion of assimilation, British colonial education is believed to have emphasized instead the "strengthening of the solid elements of the countryside. ${ }^{19}$ We now consider each of these ideologies separately.

\footnotetext{
${ }^{9}$ See Gifford \& Louis (1971:700), Thorn (2000:25) and Cain \& Hopkins (1993:218-19).
} 


\subsection{French Colonial Ideology of Educational Transfers}

The French assimilatory policy in education was rooted in an imperial ideology that colonies were one and indivisible with France. In the official French mind, France had no colonies, but departments, Thorn (2000:27). Several authors argue that French colonial education, was aimed at making Frenchmen of Africans. ${ }^{10}$ Hence, the way in which education was generally administered in French African colonies was by boarding primary pupils in far-away schools, where they were taught by French teachers, using the French language and French textbooks. ${ }^{11}$ These pupils only returned to their villages during the long vacations. It has also been argued that, the content of educational programs in French African colonies aimed essentially at alienating the elites from their own culture and society.

For instance, Gifford \& Louis (1971:697) report that history textbooks in use in French African colonies were written in such a way as to encourage Africans to deny the validity of their own cultural traditions and to admire instead those of the French. Gifford \& Louis (op.cit) further contend that while attempts were made to teach the African about their own milieu, they were nevertheless continuously reminded that everything about their environment was inferior to France and the French way of life. Therefore, if African students did master their lessons well, it should be difficult to imagine how they could have done so without internalising the assumptions, standards and prejudices of French culture and society.

In addition, through well tailored educational curricula, black francophone African elites were systematically led into believing in France's superiority in the military, technical, scientific, economic and cultural fields, and it was therefore logical for these elites to seek to share in the benefits of this superiority through continued imperial relationship with France, Chafer (2002).

Furthermore, it is claimed that an important offshot of the assimilatory education offered to Francophone African elites was that these elites became alienated from the rest of their countrymen, resulting in an idyllic sense of dependency of these elites on France. For instance, Francophone African elites were given French citizenship, and some of them even became ministers and paliamentarians in the French cabinet and legislature

\footnotetext{
${ }^{10}$ See for instance, Anne Raffenel (1856), Gifford \& Louis (1971:552) and Mazrui \& Tidy (1984:377).

${ }^{11}$ Gifford \& Louis (1971:552) have argued that the main idea behind the insistence on French as the medium of instruction is because French colonial authorities believed that by speaking French, the natives would ultimately end up thinking in French and feeling French.
} 
in Paris whilst the general population was subjected to the punitive "code d'indigénat". ${ }^{12}$ This discriminatory code not only denied rights to French citizenship to the population masses, but also subjected them to a punitive taxation system and forced labour. This discriminatory treatment of elites probably explains why Chipman (1989:86) has argued that in French black Africa:

"independence was intentionally granted as a "gift" whose acceptance by the newly created states was implicitly meant to ensure a close relationship with France".

Finally, some authors have argued that French colonial education was designed to create an 'administrative bourgeoisie' that depended highly on the colonial bureaucracy for its survival. The protagonist of this viewpoint is Moumouni (1968:46) ${ }^{13}$ who described French colonial education as:

"cut rate, designed to secure subordinate officials by impoverishing their spiritual life and detaching them completely from their own people, and that it produced an anti-national, bureaucratic neo-bourgeoisie"

Based on the preceding, two important inferences can be made about French colonial education practice in black Africa. Firstly, it created an elite that was least inclined to entering into violent confrontation with France. Put alternatively, French assimilatory educational practice produced a bunch of elites who were naturally inclined to favouring a continuation of the imperial relationship with France, instead of advocating for "real" independence as their anglophone peers did.

The second major inference about French colonial education is that it contributed in destroying the traditional and cultural ties of the elites with their countrymen, ${ }^{14}$ implying that francophone elites were more likely to face serious collective action problems in rallying the support of the general population in rebellion against the French. A few anecdotes will help elucidate these points.

In 1951, during the peak of independence struggles in Africa, the "to-be" first Ivorian President Houphouët Boigny is quoted to have declared that:

\footnotetext{
${ }^{12}$ The indigénat was a legislative code that allowed colonial officials to punish any African subject with a prison sentence or a fine, as a matter of discipline and without trial, Chafer (op.cit).

${ }^{13}$ Gann \& Duignan (1970) also argue that the type of education given to Francophone African graduates made them more inclined to government employment than their counterparts in British colonies.

${ }^{14}$ Both Suret-Canale (1971) and Cohen (1971) have supporting evidence to this hypothesis.
} 
"independence was not the best solution for Africa"15

Another emblematic figure of French assimilation in West Africa, Leopold Senghor of Senegal, ${ }^{16}$ who together with Houphouët Boigny became ministers in the French government and staunch advocates of the French Union ensuring that French interests prevailed even when the empire started crumbling, is quoted to have declared in an interview in 1955 that:

"What I fear is that, in the future, under the fatal pressure of African liberation, we might be induced to leave the French orbit. We must stay not only in the French Union but in the French Republic ${ }^{17 "}$

Yet another prominent francophone West African elite, Blaise Diagne, who became Senegal's black deputy to the French Paliament between 1914-1934, is quoted after a meeting of the second Pan-African Conference held in 1921 in Paris to have declared that:

"his loyalty to France came ahead of his loyalty to other blacks"18"

Evidently, the French were more successful in cultivating a small black elite to whom they accorded full rights of citizenship in France, on condition of course, that these elites accept assimilation into French society and reject their African heritage, family law and customs. No doubt these elites saw themselves and were seen as Frenchmen brought up in a tradition of loyalty to France, willingly accepting its government, its language and culture, which was not the case with Anglophone West African elites. ${ }^{19}$ Cohen (1971:204) concludes that:

"independence has by no means broken the close ties between France and its former colonies. The legacy of assimilation has continued. France more than any other former colonial power feels committed to aiding her dependencies and the French government gives her former colonies in Black Africa more aid than does Britain to her entire commonwealth, which contains fifteen times as large a population".

\footnotetext{
${ }^{15}$ See Meredith (2005:63)

${ }^{16}$ Senghor is also reputed to have made the famous remark that "To be a Frenchman above all is an excellent prescription on the political level". Meredith (2005:59).

${ }^{17}$ Quoted in Meredith (2005:61).

${ }^{18}$ Quoted in Gifford \& Louis (1971:842).

${ }^{19}$ Thomas Hodgkin (1954) in Meredith (2005) posits that any black African who was politically conscious in British West Africa was automatically an anti-colonial nationalist of some kind.
} 


\subsection{British Colonial Ideology of Educational Transfers}

British colonial education practice was firmly inscribed in a colonial governance philosophy of "indirect rule". As Gifford \& Louis (1971:700) have argued, the idea of indirect rule was firmly rooted in the fears expressed by the colonial administration of releasing a pool of "unemployable" school leavers and the potential threat that constituted members of this group on the rest of the population. This view is confirmed in this statement in 1920 by the Colonial Governor of Berber Province (Sudan):

"our purpose is to strengthen the solid elements in the countryside...before the irresponsible body of half-educated officials, students and town riff-raff takes control of the public mind ${ }^{20 "}$

As Gifford \& Louis (1971) argue further, the un-intended consequence of wanting to strengthen the "solid elements" in the countryside was that British colonial education policy became tailored to emphasize village schools and the preservation of local realities as well as the indigenous way of thinking. Thus, the strengthening of the "solid elements" was manifested through the administration of instruction at the elementary and primary levels in the villages, using native teachers and the local vernacular languages of the indigenous populations.

Unlike French colonial education, the preservation of the indigenous patterns of thinking and traditions were a key priority of British colonial education ideology as can be observed from this recommendation from the Advisory Committee on Native Education in the British Tropical Dependencies in $1925^{21}$ :

"Education should be adapted to the mentality, aptitudes, occupations and traditions of the various peoples, conserving as far as possible all sound and healthy elements in the fabric of their social life; adapting them where necessary to changed circumstances and progressive ideas as an agent of natural growth and evolution..."

In addition, British colonial education policy allowed a preponderant role to missionary bodies in educational provision which largely accounts for the widespread expansion

\footnotetext{
${ }^{20}$ Quoted in Gifford \& Louis (1971:700) and also in Thorn (2000:25) from Cain \& Hopkins (1993:21819).

${ }^{21}$ Quoted in Gifford \& Louis (1971:688).
} 
of education in British colonies as opposed to French colonies. This also increased the likelihood of inclination of anglophone nationalist elites to anti-capitalist political ideologies (or betterstill, socialist philosophies) due to improper monitoring. As Foster (1965:139) puts it:

"Western education was indirectly responsible for creating a group to whom access into the highest levels of the bureaucracy was denied and who constituted the core of the early nationalist movement on the Gold Coast. It was this minority of professional lawyers and intelligentsia who supplied the leadership of nationalist activities throughout most of the colonial period".

Finally, it is arguable that the most important un-intended consequence of the British education policy of "strengthening the solid elements of the countryside", was the formation of an anglophone elite that was independent in thought and less dependent on the colonial bureaucracy for its livelihood.

Based on the foregoing, two important inferences can be made about British colonial education practice in black Africa. Firstly, the elite that was created was more inclined to entering into violent confrontation with the British colonial authorities since they never really depended on the latter for their livelihood. Secondly, British colonial education contributed in reinforcing the traditional and cultural ties of the elites with their countrymen, implying that anglophone elites were less likely to face serious collective action problems in rallying the support of the general population in rebellion against the British. A few anecdotes will help elucidate these points.

Within anglophone West African nationalist elite circles, the feeling was generally shared that European colonisation has brought about inequalities, and exploitation of the African. Thorn (2000:5) recounts a much told African joke which runs thus:

"When the whiteman came to Africa, we (the Africans) had the land and he (the whiteman) had the bibles. He said, let us close our eyes and pray. When we opened them again, he had the land and we had the bibles!"

As short as the joke might appear, it is nonetheless very profound. It depicts the impression in the anglophone African mind, that colonisation was theft, aided and abetted by the Christian religion. Both Nkrumah and Nyerere, the leading pro-socialist anglophone anti-colonial nationalists were of the firm conviction that colonisation has destroyed the essential values of African society and needed to be repealed. In an essay on African socialism in 1962, Nyerere gave an idyllic account of pre-colonial African society: 
"Everybody was a worker...Not only was the capitalist or the landed exploiter unknown... [but] capitalist exploitation was impossible. Loitering was an unthinkable disgrace... The advent of colonialism has changed all this. In the old days, the African had never aspired to the possession of personal wealth for the purpose of dominating any of his fellows. He never had labourers or factory hands to do his work for him, but then came the foreign capitalists. They were wealthy and powerful. And the African naturally started wanting to be wealthy too. While nothing seems inherently wrong with that, it has unfortunately led to exploitation. There was now need for Africans to "re-educate" themselves, to regain their former attitude of mind...in rejecting the capitalist attitude of mind which colonialism brought into Africa, we must reject also the capitalist methods which go with it". ${ }^{22}$

In summary, the story of colonial education ideologies seems to suggest that colonial educational transfers contributed to the demise of the British empire in black Africa, whereas it paradoxically fostered the continuation of France's imperialism (or neo-colonialism) in the region.

As evidence, France unlike Britain, ${ }^{23}$ still percieves its sub-Saharan African empires as permanent and the vitality of the françafrique ${ }^{24}$ is still much evident today. At the political level, this is exemplified by regular French Presidential visits and the annual Franco-African summits. On the economic front, Chafer $(1995 ; 556)$ notes that former French SSA colonies are a recipient of nearly two-thirds of all French bilateral aid since 1960. On the monetary front, the Franc CFA continues to unite France to twelve of its former SSA colonies while on the military front, France continues to maintain permanent military bases in almost all of its former SSA colonies. Of no lesser significance ofcourse, is the continued promotion of the French language and French culture in Africa through cultural cooperation and the annual summits of La Francophonie.

\footnotetext{
${ }^{22}$ Quoted in Meredith (2005:145).

${ }^{23}$ British decolonisations were generally accompanied by substantial British withdrawal from the colonies and the British government made a deliberate committment not to intervene in African affairs after independence was granted. See for instance, Gifford \& Louis (1971).

${ }^{24}$ The basis of France's traditional relations with Africa, marked by personal ties with the ruling, corrupt elites of its former colonies.
} 


\section{The Model}

We now outline a simple model to formalise the idea that the pattern of decolonisation is a function of the nature of human capital transfers from the colonisers to the indigenous elites. We consider a colonised society with three players namely, the coloniser, indigenous elites (henceforth referred to simply as, the elite) and the general population (henceforth referred to as the masses). Colonisation is exemplified by the extraction of rent from output $(Y)$ by the coloniser. The size of the elite population is defined as $L^{e}$, while the size of the general population is defined as $\left(L-L^{e}\right)$ where $L$ is the size of the total population of the country.

The elite receives a transfer $X$ from the coloniser, in the form of education, in order to enhance the productivity of the colony (as illustrated in the previous chapter). The masses instead receive a basic subsistence salary. Thus $Y$ is the total output from the colony, net of subsistence payments to the masses.

The strategy of the coloniser is to either continue colonial rule or transfer power to the elite (implying decolonisation). Continuing with colonial rule procures to the coloniser a rent, which is equivalent to $(Y)$ minus the cost of transfers to the elite $(X)$ and minus whatever is necessary to maintain stability in the colony. Alternatively, the coloniser can decide to leave the country to its own destiny.

The strategy of the elite during both colonisation and decolonisation, is to either cooperate or not cooperate with the coloniser. Cooperation with the coloniser during colonisation offers a fixed payoff to the elite equivalent to $X>0$. Non-cooperation (or rebellion), on the other hand, results in a war of independence, whose outcome is uncertain. The probability of a successful rebellion depends critically on the attitude of the masses. When the masses are in cooperation with the elite in rebellion, the probability of success is much higher than otherwise. The relationship between the elite and the masses also critically affects the strategic choices faced by the elite during decolonisation.

During decolonisation (or betterstill, after independence), the elite might choose to ask for the coloniser's protection against any future subversion of their power by the masses ${ }^{25}$ or not cooperate with the coloniser in this regard. ${ }^{26}$ If the elite choses cooperation with

\footnotetext{
${ }^{25}$ The consensus between the elite and the colonisers post independence implies cooperation in the context of this model.

${ }^{26}$ It is important to emphasize that cooperation between the post independence governing elites and the colonisers is a quid pro quo whereby the elites give up some amount of the former colony's resources in exchange for the coloniser's military backing of their regimes. An example of such a deal could be the military accords of cooperation signed between France and its former colonies in black Africa at independence.
} 
the coloniser post independence, it will have to pay an amount, $Q>0$, to the coloniser. $Q$ is the cost of purchasing the coloniser's protection against possible subversion of the power of the elite by the masses.

Alternatively, if the elite choose not to cooperate with the coloniser post independence, $Q$ is zero. However, in this case, the elite will have to incur whatever costs that is necessary in order to maintain stability in the country.

The strategy of the masses during both colonisation and decolonisation is to either cooperate with the elite in all the choices that the elite make or never cooperate with them in this regard. The decision of the masses to cooperate or not cooperate with the elite is a function of the credibility of the elite, generically intended as the degree of trust that the masses have in the elite's promises. Credibility of the elite in turn, is a function of the nature of human capital transfers that they receive from the coloniser. Accordingly, the elite is perceived as credible by the masses whenever the nature of human capital transfers to the elite emphasize "local adaptation" or "non-alienation". ${ }^{27}$ In contrast, the elite is perceived as non credible whenever the nature of human capital transfers emphasize "assimilation" of the elite. ${ }^{28}$

When the elite is credible, the optimal strategy of the masses is to always cooperate with them, both during colonisation and decolonisation. Cooperation with the elite during colonisation results in a fixed payoff to the masses, equivalent to a basic subsistence salary. Cooperation with the credible elite during decolonisation, instead procures an expected income to the masses, based on a promise by the elite to share the gains of decolonisation with them. ${ }^{29}$ By definition, the option of the masses not cooperating with a credible elite is excluded.

In the opposite scenario of a non credible elite, the optimal strategy of the masses is always non-cooperation with these elite both during colonisation and decolonisation. Cooperation of the masses during colonisation always yields a basic subsistence salary received from the coloniser, whereas cooperation during decolonisation also yields a basic salary, received this time from the elite. Non-cooperation of the masses during colonisation and decolonisation also procures a fixed income to the masses ${ }^{30}$ with the added difference

\footnotetext{
${ }^{27}$ This is a reasonable axiom in the sense that when human capital transfers emphasize local realities, the traditional ties of the elite with the masses are maintained, implying that the elite is less likely to face serious collective action problems.

${ }^{28}$ Similarly, this is a reasonable axiom in the sense that an assimilated elite is detached from the masses and consequently, more likely to face serious collective action problems.

${ }^{29}$ Theoretically, this expected income is higher than the subsistence salary received by the masses during colonisation.

${ }^{30}$ The fixed salary to the masses in this case is expected to be lower than the salary when the masses
} 
that the coloniser now incurs an extra cost for repressing the masses denoted by $C_{m}^{c}$.

Assumption 1 When the coloniser follows an "assimilation" strategy ("French"), the elite is alienated from the masses and is therefore perceived by the latter as noncredible. Thus, the coloniser incurs a cost of repression, $C_{m}^{c}$, associated with the fact that the masses are not cooperating with the elites.

Thus, during colonial rule, the payoff for the coloniser is $\left(Y-X-C_{m}^{c}\right)$ and the payoff for the elite is $\frac{X}{L^{e}}$

Assumption 2 When the coloniser follows a "non-alienation" strategy ("British"), the elite is more connected with the masses, and is therefore perceived by the latter as credible. In this case, the size of the elite, $L^{e^{\prime}}$ is larger $\left(L^{e^{\prime}}>L^{e}\right)$, and the cost of repression for the coloniser is zero, for simplicity.

Thus, during colonial rule, the payoff for the coloniser is $(Y-X)$ and the payoff for the elite is $\frac{X}{L^{e^{\prime}}}$

Given this simple set up, the stage game can be summarised as follows:

- The society starts in colonisation

- The coloniser decides whether to continue with colonisation or leave the country

- Under colonisation, the elite decides whether to start a revolt while under decolonisation, the elite decide whether to pay for the coloniser's protection

- In both colonisation and decolonisation, the masses have to decide whether to cooperate with the elite.

- Nature defines the order of probabilities as follows: $0<p_{w}^{\prime \prime}<p_{w}<p_{w}^{\prime}<1$, where

- $p_{w}^{\prime \prime}$ is the probability of non-credible elites winning a war of independence against colonisation,

- $p_{w}$ is the probability of non-credible elites winning a post-independence war of rebellion engaged by the masses,

- $p_{w}^{\prime}$ is the probability of the "non-credible elite - coloniser" front winning a post-independence war of rebellion engaged by the masses.

And $p_{w}^{\prime \prime \prime}$ is the probability of credible elites winning a war of independence against colonisation. By definition, $0<p_{w}^{\prime \prime}<p_{w}^{\prime \prime \prime}<1$.

are cooperating. 
The intuition for this order of probabilities is that, non-credible elites, by virtue of the fact that they lack the support of the general population, might find it more difficult to overturn the colonial regime than credible elites (who have the support of the masses behind them). An example of such a scenario include, the Nkwame Nkrumah rebellion in 1951 that easily brought down the British Gold Coast Empire whilst, similar rebellion by the revolutionary leaders - Um Nyobe, Ernest Wandji and Felix Moumie in French Cameroon during the late 1950s, were systematically crushed down.

Likewise, the intuition for supposing that the probability of non-credible elites winning a war of independence against colonisation $\left(p_{w}^{\prime \prime}\right)$ should be lower than the probability of the same elites winning a post-independence war of rebellion waged by the masses $\left(p_{w}\right)$, is based on the simple logic of fighting technologies. Here, it is explicitly assumed that the colonisers have a more efficient fighting technology than by the masses. Similarly, a joint "coloniser - non-credible elites" front is much more likely to crush any subversive attempts by the masses, than if non-credible elites alone were to face the masses, justifying why $p_{w}^{\prime \prime}<p_{w}^{\prime}$.

To simplify the exposition, we assume that the decision of the masses to cooperate with a credible elite (or not cooperate with a non-credible elite) is irreversible.

Given the set up of the game described above, we now divide the game into two depending on the strategic choices of the masses. In the first subgame, we analyse the payoffs when the masses are never cooperating with the elite during colonisation and decolonisation (that is, the case of assimilated or non-credible elite), while in the second subgame we analyse the payoffs when the masses always cooperate with the elite (independent or credible elite scenario). We then solve each subgame by backward induction.

\subsection{Subgame I - Colonisation and Decolonisation with Assimi- lated or Non-Credible Elite}

Refering to the game tree of assimilated elites illustrated in Figure 2 below, the coloniser has the choice of continuing colonial rule (stay) or decolonising (leave). If the coloniser chooses to stay and the elite cooperate with them, there is colonial rule with repression of the masses as a result of the fact that the masses are not cooperating with the elite. The payoffs to the coloniser and non-credible elites in this case are respectively, $Y-X-C_{m}^{c}$ and $\frac{X}{L^{e}}$.

If instead the coloniser stays and the elite refuses to cooperate with colonial rule, a war of independence will ensue in which the coloniser attempts to depose, replace or 


\section{Decision Rule of Masses: Never Cooperate with Elites}

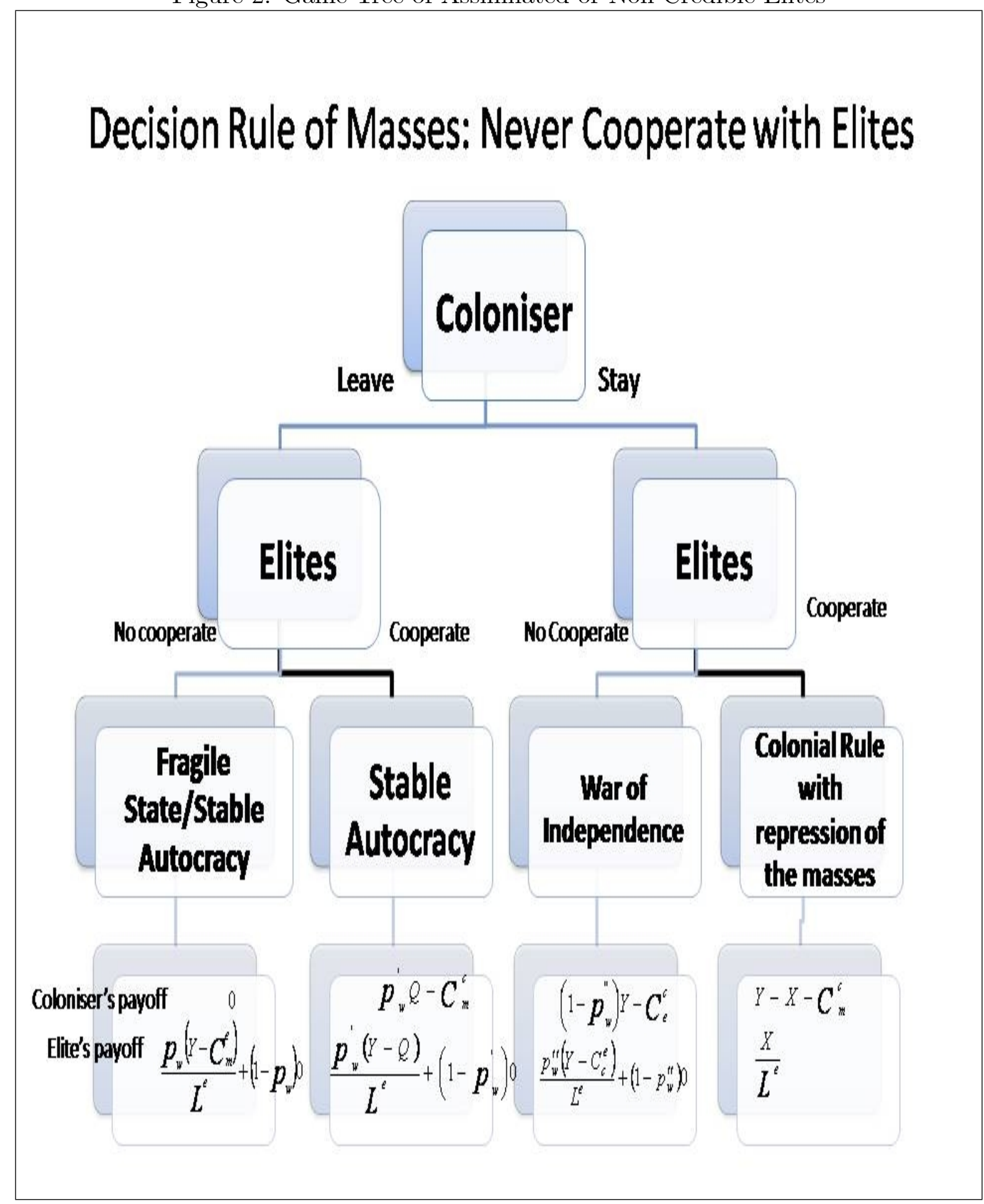


even exterminate the elites. ${ }^{31}$ In this case, the pay-off to the coloniser is $\left(1-p_{w}^{\prime \prime}\right) Y-C_{e}^{c}$ where $p_{w}^{\prime \prime}$ is the probability of non-credible elites winning a war of independence against the coloniser, and $C_{e}^{c}$ is the cost to the coloniser of making war with the elites alone. Correspondingly, the pay-off to non-credible elites is $\frac{p_{w}^{\prime \prime}\left(Y-C_{c}^{e}\right)}{L^{e}}$, where $C_{c}^{e}$ is the cost that assimilated elites incur for engaging the coloniser in a war of independence. $C_{c}^{e}$ is defined for the range $0<C_{c}^{e}<\infty$ because of the likelihood of extermination of rebellious elites.

Alternatively, if the coloniser chooses to leave and the elites ask for continued cooperation thereafter, a stable autocracy is installed in the country. The pay-off to the coloniser in this case is $p_{w}^{\prime} Q-C_{m}^{c}$, where $C_{m}^{c}$ is the costs that the coloniser incurs in maintaining stability in the country post independence. ${ }^{32} p_{w}^{\prime}$ is the probability of the "non-credible elite - coloniser" front successfully suppressing any post independence rebellion by the masses, and $Q$ is the cost to elites of maintaining the post independence imperial relationship with the coloniser. Correspondingly, the pay-off to non-credible elites is $\frac{p_{w}^{\prime}(Y-Q)}{L^{e}}$.

Finally, in the event that the coloniser leaves and the elite choose to go without the coloniser's protection, two outcomes are feasible depending on the character of the elite (or its ability to effectively repress the masses). If the elite is able to effectively repress the masses (probably because of its military capabilities), a stable autocracy will emerge in the country. However, if the elite's ability to repress the masses is questionable, a fragile state will emerge post independence. The pay-offs to the coloniser and non-credible elites in this instance are 0 and $\frac{p_{w}\left(Y-C_{m}^{e}\right)}{L^{e}}$ respectively, where $p_{w}$ is the probability of noncredible elites winning a post independence war of rebellion against the masses, and $C_{m}^{e}$ is the cost that non-credible elites incur in waging war with the masses post independence.

\section{Solution of the subgame}

Since the strategy of the masses is never cooperate with the elites during colonisation and decolonisation, the elite is faced with two choices - either cooperate or not cooperate with the coloniser.

Cooperation is always a dominant strategy for non-credible elites if and only if the latter's payoff from cooperation during colonisation (and correspondingly, during decolonisation) is higher than its payoff from non cooperation. Referring to Figure 2 above, this implies that:

\footnotetext{
${ }^{31}$ For simplicity, we assume that the elites always get a payoff of zero for loosing either in the war of independence against the coloniser or in a post independence war of rebellion engaged by the masses.

${ }^{32}$ We have assumed for simplicity, that the costs the coloniser incurs in maintaining stability in the country is the same during colonisation and decolonisation.
} 


$$
\frac{X}{L^{e}}>\frac{p_{w}^{\prime \prime}\left(Y-C_{c}^{e}\right)}{L^{e}}
$$

and

$$
\frac{p_{w}^{\prime}(Y-Q)}{L^{e}}>\frac{p_{w}\left(Y-C_{m}^{e}\right)}{L^{e}}
$$

Given the non-credible elite's dominant strategy of cooperation, decolonisation is a dominant strategy for the coloniser if and only if:

$$
p_{w}^{\prime} Q-C_{m}^{c}>Y-X-C_{m}^{c}
$$

Proposition 1 There exists a range of feasible values of $Q$, that is, $\left(\frac{Y-X}{p_{w}^{\prime}}<Q<C_{m}^{e}\right)$, for which the payoff from decolonising are higher than those from colonial rule.

Proof. Equation 1 above simply says that, non-credible elites will cooperate with colonial rule as long as the per capita transfer that they recieve from the coloniser is greater than their expected gains from not cooperating.

Equation 2 implies that:

$$
p_{w}^{\prime}(Y-Q)>p_{w}\left(Y-C_{m}^{e}\right) \Longrightarrow Q<\frac{p_{w}}{p_{w}^{\prime}} C_{m}^{e}+\frac{p_{w}^{\prime}-p_{w}}{p_{w}^{\prime}} Y
$$

defining $\frac{p_{w}}{p_{w}^{\prime}}=-\left(\frac{p_{w}^{\prime}-p_{w}}{p_{w}^{\prime}}-1\right)=1-\alpha$ where $\alpha=\frac{p_{w}^{\prime}-p_{w}}{p_{w}^{\prime}} ; 0 \leq \alpha \leq 1$.

$$
\Longrightarrow Q<(1-\alpha) C_{m}^{e}+\alpha Y
$$

Equation 4 above suggests that there exists an upper bound of $Q$, that is, $\left(Q<C_{m}^{e}\right)$ when $\alpha=0$, or when $p_{w}^{\prime}=p_{w}$ for which decolonisation is rational for the coloniser.

Equation 3 above implies that:

$$
Q>\frac{Y-X}{p_{w}^{\prime}}
$$

Hence, equation 5 suggests that there exists a lower bound of $Q$, equal to $\frac{Y-X}{p_{w}^{\prime}}$, for which the coloniser is willing to decolonise.

Combining equations 4 and 5 above gives:

$$
\frac{Y-X}{p_{w}^{\prime}}<Q<C_{m}^{e}
$$


Equation 6 above defines the feasible range of $Q$, for which decolonisation occurs. In other words, equation 6 defines the range of feasible gains which the coloniser is willing to accept in exchange for its protection of the power of the post independence governing elites from subversion by the masses.

\section{Intuition and Implications of the Results}

Given the elite's dominant strategy of always cooperating with the coloniser, the main factors that determine the switch from colonisation to neo-colonialism are namely, the output from the colony $(Y)$, the amount of transfers made by the coloniser to the elite $(X)$, and the probability of the "non-credible elites - coloniser" alliance successfully suppressing future subversion by the masses $\left(p_{w}^{\prime}\right)$, as demonstrated in equation 5 above.

The above named parameters are largely at the appreciation of the coloniser, suggesting that the initiative to decolonise in this case primarily originates from the coloniser. Consequently, this analysis fits well with the Eurocentric explanation of decolonisation, which claims that the colonisers left mainly because the utility from being a coloniser was declining.

Accordingly, this scenario best depicts the French decolonisation process in sub-Saharan Africa where France is known to have suddenly and unilaterally transformed all of its 16 former colonies ${ }^{33}$ into independent republics in the same year (1960). ${ }^{34}$

\subsection{Subgame II - Colonisation and Decolonisation with Inde- pendent or Credible Elite}

Refering to the game tree of independent elites illustrated in Figure 3 below, the coloniser has the choice of either staying or leaving. If he stays and the elite cooperate with him, there is colonial rule without repression of the masses. Accordingly, the payoffs to the coloniser and credible elites are respectively, $Y-X$ and $\frac{X}{L^{e^{\prime}}}$.

If instead the coloniser stays and the elite refuse to cooperate with colonial rule, a war of independence will ensue in which the coloniser attempts to depose, replace or even exterminate the elites. In this case, the pay-off to the coloniser is $\left(1-p_{w}^{\prime \prime \prime}\right) Y-C_{e m}^{c}$ where $C_{e m}^{c}$ is the cost the coloniser incurs in waging war against a joint elite-mass nationalist front and $p_{w}^{\prime \prime \prime}$ is the probability of credible elites winning a war of independence against the

\footnotetext{
${ }^{33}$ Except for Guinea that had earlier bolted out of the French Community.

${ }^{34}$ See for instance, Birmingham (1995:26) where the author argues that French colonialism had given way to neo-colonialism as the ties between France and the new republics is no longer constitutional but cultural and commercial.
} 


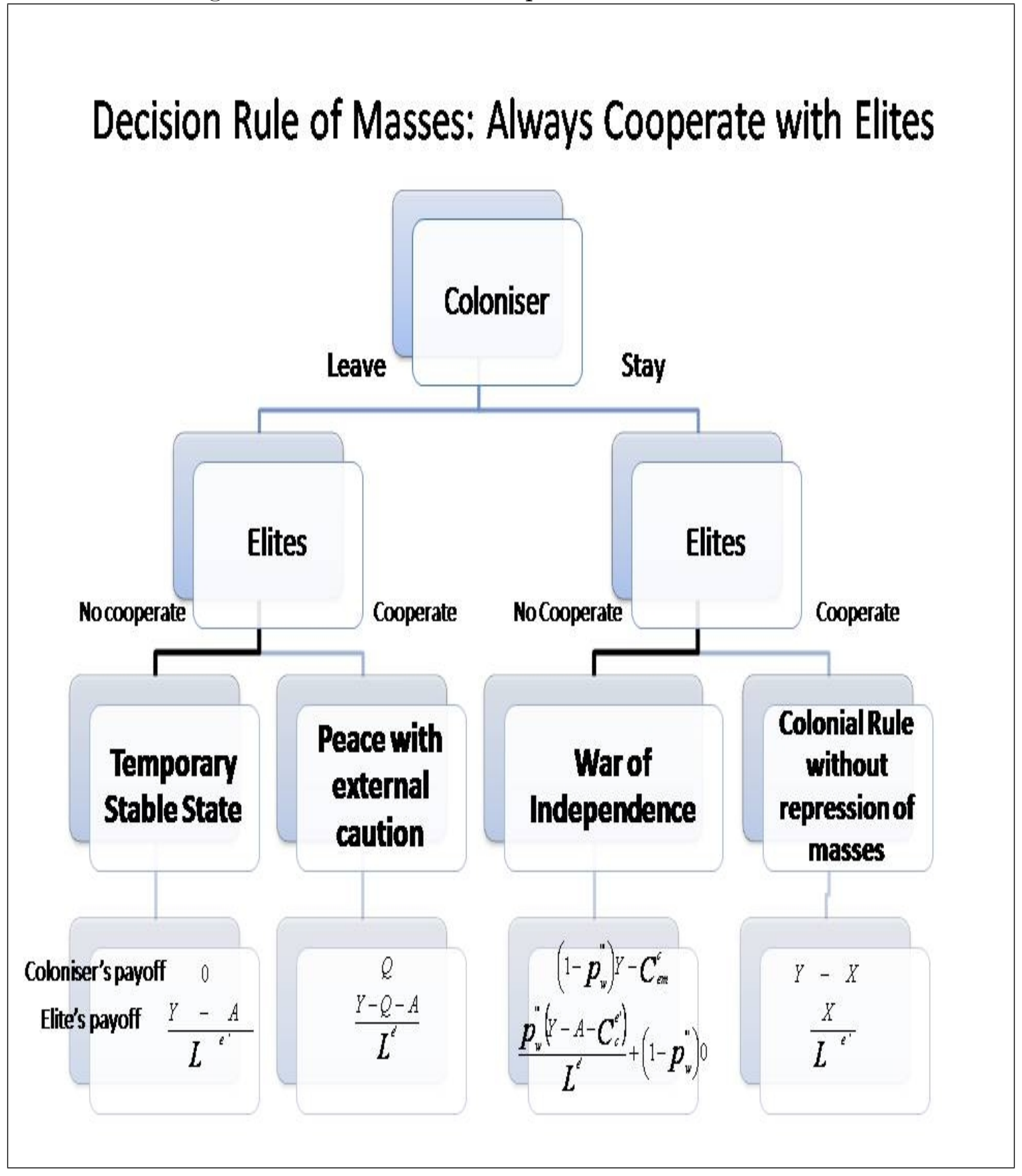


coloniser. Correspondingly, the pay-off to credible elites is ${ }^{35} \frac{p_{w}^{\prime \prime \prime}\left(Y-A-C_{c}^{e^{\prime}}\right)}{L^{e \prime}}$, where $A>0$, is an indirect cost that credible elites incur in rebellion against the coloniser (specifically, it is a fixed transfer that they pay in order to purchase the cooperation of the masses) and $C_{c}^{e^{\prime}}$ is the cost that credible elites incur directly for fighting against the coloniser.

Alternatively, if the coloniser chooses to leave and the elites ask for continued cooperation thereafter, the outcome of this scenario might be peace cautioned by external protection from the coloniser and the pay-offs are $Q$, and $\frac{Y-Q-A}{L^{e^{\prime}}}$ to the coloniser and credible elites respectively. ${ }^{36} \quad Q$ is as defined in the preceding scenario of non-credible elites.

Finally, in the event that the coloniser leaves and the elite choose to go without the coloniser's protection, this might result in "complete" independence, although the cooperation ties existing between the elites and masses might not necessarily be sustained afterwards. ${ }^{37}$ The resulting pay-offs are thus 0 and $\frac{Y-A}{L^{e^{\prime}}}$ for the coloniser and credible elites respectively, where $A$ in this case, is the amount of transfers needed by the elites to purchase peace with the masses after the coloniser departs.

\section{Solution of the subgame}

Since the strategy of the masses is always cooperation with the elites during colonisation and decolonisation, the elite is faced with two choices - either cooperate or not cooperate with the coloniser.

Non-cooperation is always a dominant strategy for credible elites if and only if the latter's payoff from non-cooperation during colonisation (and correspondingly, during decolonisation) is higher than its payoff from cooperation. Referring to Figure 3, this implies that:

$$
\frac{p_{w}^{\prime \prime \prime}\left(Y-A-C_{c}^{e^{\prime}}\right)}{L^{e^{\prime}}}>\frac{X}{L^{e^{\prime}}} \Rightarrow p_{w}^{\prime \prime \prime}\left(Y-A-C_{c}^{e^{\prime}}\right)>X
$$

which simplifies to:

\footnotetext{
${ }^{35}$ Note that as before, we assume for simplicity that the payoff to the elites for loosing the war of independence is always zero.

${ }^{36}$ Following the initial premise that the masses always cooperate with independent elites, an implicit assumption has been made that $A$, the cost to independent elites of purchasing the cooperation of the masses, is the same during colonisation and decolonisation.

${ }^{37}$ It is worth mentioning that a new form of strategic bargaining for the control of resources might likely arise between the elites and the masses post independence which might probably jeopardize the "entente" between the two groups. Fedderke \& Kularatne (2008) have a nice exposition of this scenario.
} 


$$
Y>\left(\frac{X}{p_{w}^{\prime \prime}}+A+C_{c}^{e^{\prime}}\right)
$$

and

$$
\frac{Y-A}{L^{e}}>\frac{Y-Q-A}{L^{e}}
$$

Observe also that as long as $Q>0$, equation 9 is always true.

Given the credible elite's dominant strategy of non-cooperation, decolonisation is a dominant strategy for the coloniser if and only if:

$$
0>\left(1-p_{w}^{\prime \prime \prime}\right) Y-C_{e m}^{c}
$$

Proposition 2 As the probability of elite nationalist movements winning a war of independence against the coloniser approaches unity, the coloniser is better-off quiting the scene and there exists a range of feasible values of output, $Y$, that is, $\left(\frac{X}{p_{w}^{\prime \prime \prime}}+A+C_{c}^{e^{\prime}}\right)<$ $Y<\frac{C_{e m}^{c}}{\left(1-p_{w}^{\prime \prime \prime}\right)}$ for which the coloniser is better-off decolonising.

Proof. Equation 8 above defines the minimum bound of output produced in the colony, $Y$, which guarantees elites non-cooperation with colonial rule. It suggests that as long as the output produced in the colony is at least greater than the combined costs to the credible elites of, buying the support of the masses in rebellion against the coloniser $(A)$ and making war with the coloniser $\left(C_{c}^{e}\right)$, the elites will always rebel against colonisation.

On condition that $C_{e m}^{c}>0$, equation 10 implies that as the probability of success of elite-led war of independence against the coloniser rises, (i.e. $p_{w}^{\prime \prime \prime} \longrightarrow 1$, ), the coloniser is better off leaving. Equation 10 also suggests that decolonisation might become a rational option for the coloniser when nationalism is strong, that is, as $C_{e m}^{c} \longrightarrow \infty$.

Equation 10 can also be re-arranged in the following way:

$$
Y<\frac{C_{e m}^{c}}{\left(1-p_{w}^{\prime \prime \prime}\right)}
$$

Combining equations 8 and 11 above yields:

$$
\frac{X}{p_{w}^{\prime \prime \prime}}+A+C_{c}^{e^{\prime}}<Y<\frac{C_{e m}^{c}}{\left(1-p_{w}^{\prime \prime \prime}\right)}
$$

Equation 12 above defines the range of feasible values of output produced in the colony, $Y$, for which it is no longer expedient for the coloniser to stay. 


\section{Intuition and Implications of the Results}

The solution of the preceding subgame suggests that, when the elites are credible, they will always find it optimal to rebel against the coloniser as long as the output produced in the colony is at least greater than $\left(A+C_{c}^{e \prime}\right)$.

The results above suggest that the coloniser might attempt to resist the rebellion of the elites, as long as the coloniser's cost of engaging in a war of independence, $C_{e m}^{c}$, is less than a fraction $\left(1-p_{w}^{\prime \prime \prime}\right)$ of total output, $Y$. However, as $C_{e m}^{c}$ rises indefinitely, or as the probability of nationalist elites winning a war of independence approaches unity $\left(p_{w}^{\prime \prime \prime} \longrightarrow 1\right)$, there is no other option left for the coloniser but to switch from fighting a war of independence to granting full independence. Equation 12 above defines the range of feasible values of total output produced in the colony that guarantees the switch from colonisation to independence.

The way that these results should be understood is that, in contrast with the preceding case of assimilated elites, human capital transfers from the coloniser to the elites in this case serve also in resolving elites' collective action problems which potentially raises both $C_{e m}^{c}$ and $p_{w}^{\prime \prime \prime}$, until it is no longer feasible for the colonisers to stay. This scenario therefore upholds the Afrocentric explanation of decolonisation.

Typical examples of decolonisation processes depicted by this scenario are the British decolonisations in most of sub-Saharan Africa, where Britain characteristically engaged in wars of independence with nationalist movements before finally conceding to independence. $^{38}$ It is perhaps worth recalling that independence in many former British colonies in Africa was generally followed by political instability as a result of the emergence of a new strategic bargaining between the elites and the masses.

Other examples include the decolonisation of the Lusophone states of Guinea-Bissau, Angola and Mozambique where nationalist organisations engaged in protracted guerrilla warfare with Portugal before the latter finally conceded to independence. Furthermore, independence in the Lusophone African countries generally resulted in fragile states as prolonged post-colonial wars ensued between rival nationalist factions seeking to control economic resources.

\footnotetext{
${ }^{38}$ The characteristic pattern of transfer of power by Britain in sub-Saharan Africa consisted first in procrastination, followed by a phase of violence begets violence, then finally conceding to complete independence, Thorn (2000).
} 


\subsection{Variants of Subgame I - Colonisation \& Decolonisation with Assimilated Elite}

Continuing to refer to Figure 2 above, we now discuss scenarios whereby cooperation with the coloniser is no longer a dominant strategy of non-credible elites. We distinguish three cases namely, where assimilated elites cooperate with the coloniser during colonial rule but refuse cooperation after independence, where assimilated elites always refuse cooperation with the coloniser both during colonial rule and after independence, and where assimilated elites do not cooperate with the coloniser during colonial rule but cooperate after independence.

1st Variant: Assimilated elites cooperate with the coloniser during colonial rule but refuse cooperation after independence. The independence outcome is either a stable autocracy or a fragile state depending on the character of the elites.

From Figure 2 above, cooperation with the coloniser during colonial rule is a dominant strategy for assimilated elites if and only if:

$$
\frac{X}{L^{e}}>\frac{p_{w}^{\prime}\left(Y-C_{c}^{e}\right)}{L^{e}} \Rightarrow X>p_{w}^{\prime \prime}\left(Y-C_{c}^{e}\right)
$$

On the other hand, non-cooperation with the coloniser post independence is a dominant strategy for assimilated elites if and only if:

$$
\frac{p_{w}\left(Y-C_{m}^{e}\right)}{L^{e}}>\frac{p_{w}^{\prime}(Y-Q)}{L^{e}}
$$

which simplifies to:

$$
C_{m}^{e}<(1-\beta) Q+\beta Y \quad \text { where } \beta=\frac{p_{w}-p_{w}^{\prime}}{p_{w}}
$$

Given the above choices of the elites, the coloniser's dominant strategy is to decolonise if and only if:

$$
0>Y-X-C_{m}^{c} \Longrightarrow\left(X+C_{m}^{c}\right)>Y
$$

Equation 13 above suggests that assimilated elites' dominant strategy of non-cooperation with the coloniser post independence is largely dependent on the elites' ability to effectively repress the masses. As long as the elites cost of repressing the masses, $C_{m}^{e}$, is less than what is needed to purchase the coloniser's protection, $Q$, the elite always refuses 
cooperation with the coloniser post independence.

Equation 14 suggests that whenever the costs of colonial rule is greater than the coloniser's derived utility from empire, it makes sense to decolonise.

The combined interpretation of equations 13 and 14 above suggests that the pattern of decolonisation whereby elites cooperate with the coloniser during colonisation but refuse cooperation after independence is feasible under two simultaneous conditions namely,

1 - whenever the colony is no longer profitable to the coloniser

2 - and as long as the elites are capable of effectively suppressing any post independence subversion by the masses.

This could be the case that the elites form part of the military. This scenario unifies both the Eurocentric and Afrocentric explanations of decolonisation because the utility derived from empires as well as the character of the elite (or specifically, its ability to repress the masses) both matter in the decision to decolonise.

2nd Variant: Assimilated elites always refuse cooperation with the coloniser both during colonial rule and after independence. The independence outcome could either be a stable autocracy or a fragile state depending on the character of the elite.

Referring to Figure 2 above, non-cooperation with the coloniser during colonisation is a dominant strategy for assimilated elites if and only if:

$$
p_{w}^{\prime \prime}\left(Y-C_{c}^{e}\right)>X \Longrightarrow p_{w}^{\prime \prime}>\frac{X}{\left(Y-C_{c}^{e}\right)}
$$

On the other hand, non-cooperation with the coloniser post independence is a dominant strategy for assimilated elites if and only if:

$$
\begin{gathered}
\frac{p_{w}\left(Y-C_{m}^{e}\right)}{L^{e}}>\frac{p_{w}^{\prime}(Y-Q)}{L^{e}} \\
\Longrightarrow C_{m}^{e}<(1-\beta) Q+\beta Y
\end{gathered}
$$

where $\beta$ is as previously defined.

Given the above choices of the elites, the coloniser's dominant strategy is to decolonise if and only if:

$$
0>\left(1-p_{w}^{\prime \prime}\right) Y-C_{e}^{c}
$$




$$
\Longrightarrow p_{w}^{\prime \prime}>1-\frac{C_{e}^{c}}{Y}
$$

Equation 17 above suggests that the coloniser will leave whenever the probability of elites winning the war of independence rises above $\left(1-\frac{C_{e}^{c}}{Y}\right)$. Notice also that as the coloniser's cost of fighting the war of independence with the elites, $C_{e}^{c}$, rises indefinitely, it is much preferable for the coloniser to leave.

The combined interpretation of equations 15, 16 and 17 above suggests that the pattern of decolonisation whereby assimilated elites never cooperate with the coloniser during colonisation and after independence is feasible under two simultaneous conditions namely,

1 - whenever the elites' probability of winning the war of independence against the coloniser, $p_{w}^{\prime \prime}$, is greater than both $\frac{X}{\left(Y-C_{c}^{e}\right)}$ and $\left(1-\frac{C_{e}^{c}}{Y}\right)$.

2 - and as long as the elites are capable of effectively suppressing any post independence subversion by the masses.

The above conditions could either be the result of some personal revolutionary characteristic of the nationalist elites, or its appartenance to the military. This is a variant of the Afrocentric explanation of decolonisation because the character of the elite (or specifically, its ability to threaten the colonial system and repress the masses at the same time) does matter in the decision to decolonise.

An example of decolonisation that might represent this scenario is the British disengagement of Uganda where independence was achieved not so much because of the strength of nationalist movements, but precisely because of the personal charisma of military leaders such as Milton Obote and Idi Amin Dada. ${ }^{39}$

3rd Variant:Assimilated elites do not cooperate with the coloniser during colonial rule but cooperate after independence. The independence outcome is a stable autocracy.

Referring to Figure 2 above, non-cooperation with the coloniser during colonisation is a dominant strategy for assimilated elites if and only if:

$$
p_{w}^{\prime \prime}\left(Y-C_{c}^{e}\right)>X \Longrightarrow p_{w}^{\prime \prime}>\frac{X}{\left(Y-C_{c}^{e}\right)}
$$

On the other hand, cooperation with the coloniser post independence is a dominant strategy for assimilated elites if and only if:

\footnotetext{
${ }^{39}$ See Thorn (2000:54) for this evidence. Another example of decolonisation that depended much on the personal character of the elite could be the Belgians and General Mobutu of the Congo, although the post-colonial imperial relationships that Mobutu maintained do not clearly fit in this scenario.
} 


$$
Q<(1-\beta) C_{m}^{e}+\beta Y
$$

where $\beta$ is as defined before. When $\beta=0, Q$ has an upper bound defined by $C_{m}^{e}$.

Given the above choices of the elites, the coloniser's dominant strategy is to decolonise if and only if:

$$
\begin{gathered}
p_{w}^{\prime} Q-C_{m}^{c}>\left(1-p_{w}^{\prime \prime}\right) Y-C_{e}^{c} \\
\Longrightarrow Q>\left(\frac{1-p_{w}^{\prime \prime}}{p_{w}^{\prime}}\right) Y+\frac{1}{p_{w}^{\prime}}\left(C_{m}^{c}-C_{e}^{c}\right)
\end{gathered}
$$

Equation 19 above suggests a minimum bound of $Q$, for which decolonisation followed by the cooperation of assimilated elites occurs.

The combined interpretation of equations 18 and 19 above, suggests that the pattern of decolonisation whereby elites obtain independence through conflict with the coloniser yet cooperate with the latter post independence, is feasible under the following conditions namely:

1 - the elite's cost of repressing the masses (post independence) is at least greater than its cost of purchasing the coloniser's protection against the masses.

2 - and whenever the cost of purchasing the coloniser's protection, $Q$, lies within the range defined by: $\left[\left(\frac{1-p_{w}^{\prime \prime}}{p_{w}^{\prime}}\right) Y+\frac{1}{p_{w}^{\prime}}\left(C_{m}^{c}-C_{e}^{c}\right)\right]<Q<(1-\beta) C_{m}^{e}+\beta Y$

This scenario upholds both the Eurocentric and Afrocentric explanations of decolonisation. This is because the character of the elite and the expectations of the coloniser both matter in the decision to decolonise. An example of a decolonisation process that followed this route could be the French decolonisation of Algeria where the emerging nationalist leader, Ben Bella, was compelled to accept proposals of limited continuity of French imperialism after having fought one of the longest wars of decolonisation in Africa. ${ }^{40}$ Of course, Ben Bella was quickly overthrown three years later and an authoritarian rule under Boumédienne was established in the country for almost a quarter of a century.

\footnotetext{
${ }^{40}$ The Evian agreement of March 1962 between the French colonial authorities and leaders of the Algerian Liberation Front (FLN) provided for (1) a transitory period of three years for French settlers to decide whether they wanted to remain French citizens or become Algerian citizens (2) French companies to maintain their leasing rights to develop oil fields (3) and France was allowed to maintain the important naval base at Mers-el-Kebir for a minimum of fifteen years (although she withdrew as early as 1968), Thorn (2000:84).
} 


\subsection{Variants of Subgame II - Colonisation \& Decolonisation with Independent Elite}

Referring to Figure 3 above, we now discuss the unique scenario whereby non-cooperation with the coloniser is no longer a dominant strategy of independent elites.

Unique Variant: Independent elites cooperate with the coloniser during colonial rule but refuse cooperation after independence. The independence outcome could be a stable monarchy.

Cooperation with the coloniser during colonisation is a dominant strategy for independent elites if and only if:

$$
X>p_{w}^{\prime \prime \prime}\left(Y-A-C_{c}^{e \prime}\right)
$$

On the other hand, as previously observed, non-cooperation with the coloniser is always a dominant strategy for independent elites post independence.

Given the above choices of the elites, the coloniser's dominant strategy is to decolonise if and only if:

$$
0>Y-X
$$

As observed from equation 21 above, the decolonisation decision is largely the initiative of the coloniser, and is precisely because colonial rule has become unprofitable. This scenario is a classic representation of the Eurocentric perspective of decolonisation and the transfer of power is expected to occur in an amicable atmosphere.

However, in this scenario, the post-colonial elite changes its attitude towards the coloniser and becomes radical or uncompromising once independence is acquired. An example of decolonisation that depicts this scenario could be the British disengagament in Egypt whereby imperial relationship with the nationalist elites changed dramatically for the worse after independence. ${ }^{41}$ Harold Macmillan, British Prime Minister of the early 1960s, is quoted to have regretted the change in attitude of Nasser, the post-colonial Egyptian leader whom Britian had trusted, as he lamented:

"the collapse of the agreeable, educated, Liberal, North Oxford society to whom we have transferred power" 42

\footnotetext{
${ }^{41}$ Colonel Nasser, shortly after independence in July 1956, nationalised the Suez Canal, which was vital to Britain's trade and oil supplies.

${ }^{42}$ Quoted in Thorn (2000:48).
} 


\section{Summary of Core Predictions of the Model}

The results of the model predict four important differences between the French and British models of colonisation and decolonisation in West Africa:

1 - French colonisation was generally more repressive than British colonisation. On the other hand, French decolonisation was smooth and peaceful while British decolonisation was often protracted and violent. Also, the pace of transition to independence in French West Africa was generally faster than that in British West Africa.

2 - Former French West African colonies are generally more stable politically than their British counterparts after independence.

3 - During colonisation, francophone West African elites were more professionally inclined to government occupations than their Anglophone counterparts.

4 - Francophone West African elites were more disconnected from their countrymen than their Anglophone counterparts.

\section{Conclusion}

The first endeavour of this study has been to highlight the differences in British and French colonial education practices. We then used these distinguishing features in outlining a simple model which throws light into why the approaches to, and outcomes of decolonisation in these two empires have differed significantly the one from the other. Using game theoretic analysis, the study argues that the pattern of decolonisation was a function of the nature of human capital transfers from the colonisers to the indigenous elites of the former colonies, and this shaped the strategic relationship between these two groups.

Where the colonial education ideology emphasized the notion of "assimilation", the system generally tended to produce elites that depended highly on the coloniser for their livelihood, hence necessitating a continuation of the imperial relationship even after independence was obtained. On the contrary, where the ideology emphasized the strengthening of the "solid elements" of the countryside, the system tended to produce a bunch of elites that were quite independent of the coloniser and consequently had little to loose from a disruption of the imperial relationship at independence.

The model raises several predictions based on a single assumption on the nature of the indigenous elite. Specifically, the results of the model shed light into why the French decolonisation process in West Africa was generally smooth and transited from colonialism 
to neo-colonialism whereas British decolonisations in West Africa were generally antagonistic, often culminating in complete independence from England. The model also throws light into the different paths of decolonisation on the African continent. The contribution of the study has been in providing a framework for understanding the different paths of decolonisation in Africa in general, but more specifically in the British and French West African empires, an approach which unifies both the Eurocentric and Afrocentric perspectives.

\section{References}

[1] AGBOR, J.A., FEDDERKE, J.W. NICOLA, V., 2010. "How Does Colonial Origin Matter for Economic Performance in sub-Saharan Africa?" Economic Research Southern Africa (ERSA) Working Paper No. 176

[2] ANNE RAFFENEL, 1856. "Nouveau Voyage au Pays des Nègres". Paris.

[3] APTER, D. E., 1955. "The Gold Coast in Transition". Princeton Univ. Press, Princeton.

[4] ASIWAJU, A. I., 2000. "West African Transformations: Comparative Impact of French and British Colonialism". Malthouse Press Ltd.

[5] BATES, R. H., \& LOFCHIE, M. F., 1980. "Agricultural Development in Africa: Issues of Public Policy". Praeger Publishers, New York.

[6] BATES, R. H., 1981. "Markets and States in Tropical Africa". University of California Press, Berkeley.

[7] BATES, R. H., 1983. "Essays on the Political Economy of Rural Africa". Cambridge University Press. Cambridge.

[8] BIRMINGHAM, D., 1995. "The Decolonisation of Africa". UCL Press Ltd. London.

[9] BOLTON, G. C., 1973. "Britain's Legacy Overseas". Oxford University Press, Oxford.

[10] BORELLA, F., 1958. "L'Evolution Juridique et Politique de l'Union Française depuis 1946". Paris. 
[11] CAPELLE, J., 1949. "Education in French West Africa". Overseas Education, Vol. 21(10):956-72.

[12] CHAFER, T., 1995. "African Perspectives: the Liberation of France and its Impact in French West Africa", in Kedward, H.R. \& Wood, N., eds, The Liberation of France: Image and Event. Oxford:Berg.

[13] CHAFER, T., 2002. "The End of Empire in French West Africa: France's Successful Decolonization?", Oxford-New York:Berg.

[14] CHIPMAN, J., 1989. "French Power in Africa". Oxford:Blackwell.

[15] COHEN, W. B., 1971. "Rulers of Empire: The French Colonial Service in Africa". Hoover Institution Press, Stanford University.

[16] CROWDER, M., 1965. "Independence as a Goal in French West African Politics:1944-60" in W.H. Lewis, ed., French-Speaking Africa:The Search for Identity, New York.

[17] CROWDER, M., 1968. "West Africa under Colonial Rule". Hutchinson \& Co (Publishers) Ltd.

[18] DARWIN, J., 1988. "Britain and Decolonisation: the retreat from Empire in the post-war world". The Macmillan Press.

[19] Douglas, R., 1978. "The Economics of Colonialism in Africa". Journal of African History. Vol. 19 (2): 265-273.

[20] DUIGNAN, P. \& GANN, L.H., 1970. "Colonialism in Africa 1870-1960". Cambridge Univ. Press.

[21] FEDDERKE, J.W., \& KULARATNE, C., 2008. "Characterizing Conflict Forms". Annual Bank Conference on Development Economics Working Paper.

[22] GARTZKE, E., \& ROHNER, D., 2010. "The Political Economy of Imperialism, Decolonisation, and Development". Institute for Empirical Research in Economics Working Paper No. 466.

[23] GIFFORD, P., \& LOUIS, W.R., 1971. "France and Britain in Africa: Imperial Rivalry and Colonial Rule". Yale Univ. Press, New Haven and London. 
[24] GIFFORD, P., \& LOUIS, W.R., 1988. "Decolonisation and African Independence: The Transfers of Power, 1960-1980". Yale Univ. Press.

[25] GRIER, R., 1999. "Colonial Legacies and Economic Growth". Public Choice, Vol.98: 317-335.

[26] GROSSMAN, H. I., \& IYIGUN, M. F., 1995. "Extralegal Appropriation and the Profitability of Colonial Investment". Economics and Politics. Vol. 7: 229-41.

[27] GROSSMAN, H. I., \& IYIGUN, M. F., 1997. "Population Increase and the End of Colonialism". Economica. Vol. 64: 483-93.

[28] HAILEY, Lord, 1957. "An African Survey". Oxford Univ. Press, Oxford. 2nd Edition.

[29] HARGREAVES, J.K., 1988. "Decolonisation in Africa". Longman.

[30] HUNTINGTON, S.P., 1968. "Political Order in Changing Societies". New Haven: Yale University Press.

[31] KAY, G.B., \& STEPHEN, H., 1972. "The Political Economy of Colonialism in Ghana". Cambridge University Press.

[32] KLERMAN, D., P. MAHONEY, H. SPAMANN, \& M. WEINSTEIN, 2008. "Legal Origin and Economic Growth" Unpublished. Available at: http://www.law.ucla.edu/docs/klerman_paper.pdf

[33] MACAULAY, E., 1967. "British India 1772-1947". Sidgwick \& Jackson. London.

[34] MACHIAVELLI, N., 1961. "The Prince". Penguin Books. New York.

[35] MADDISON AUGUS, 1971. "Class Structure and Economic Growth". George Allen \& Unwin Ltd. London.

[36] MADDISON AUGUS, 1995. "Explaining the Economic Performance of Nations". Edward Elgar Publishing Co.

[37] MADDISON AUGUS, 2003. "The World Economy, Historical Statistics". Development Centre Studies, OECD.

[38] MARSHALL, D.B., 1973. "The French Colonial Myth and Constitution making in the Fourth Republic". Yale Univ. Press. 
[39] MARTIN MEREDITH, 2005. "The State of Africa: A History of Fifty years of Independence." Jonathan Ball Publishers (PTY) Ltd.

[40] MAZRUI, A.A., \& TIDY, M., 1984. "Nationalism and New States in Africa". Nairobi: East Africa Educational Publishers.

[41] McGOWAN, P. J., 2003. "African Military Coup d'état, 1956-2001: Frequency, Trends and Distribution". Journal of Modern African Studies, Vol. 41(3): 339-370.

[42] McWILLIAM, H.O.A., \& KWAMENA-POH, M.A., 1978. "The Development of Education in Ghana: An Outline". Longman Group Limited, London.

[43] MORGENTHAU, R.S., 1964. "Political Parties in French-Speaking West Africa". Clarendon Press, Oxford.

[44] MORTIMER, E., 1969. "France and the Africans, 1944-1960: A Political History". London.

[45] MOUMOUNI, A., 1968. "Education in Africa". New York.

[46] NUNN, N., 2007. "Historical Legacies: a model linking Africa's past to its current underdevelopment". Journal of Development Economics. Vol. 83:157-175.

[47] OLSON, M., 1982. "The Rise and Decline of Nations". New Haven and London: Yale Univ. Press.

[48] OLSON, M., 1993. "Dictatorship, Democracy and Development". American Political Science Review. Vol. 87 (3): 567-576.

[49] OWUSU-ANSAH, D., 2005. "Historical Dictionary of Ghana". Historical Dictionaries of Africa, 97. The Scarecrow Press, Inc.

[50] PAUL KENNEDY, 1989. "The Rise and Fall of the Great Powers:Economic Change and Military Conflict 1500-2000". Unwin Hyman.

[51] FOSTER, J.P., 1965. "Education and Social Change in Ghana". Routledge \& Kegan Paul, London.

[52] PIERS BRENDON, 2007. "The Decline and Fall of the British Empire: 1781-1997". Jonathan Cape, London. 
[53] RHODA HOWARD, 1978. "Colonialism and Underdevelopment in Ghana". Croom Helm London.

[54] ROSTOWsKi, J. \& B. STACESCU, 2006. "The Wig and the Pith Helmet - the Impact of 'Legal School' versus Colonial Institutions on Economic Performance" (second version). CEPR Studies \& Analysis No. 300.

[55] SMITH, T.,1982. "Patterns in the transfer of power: a comparative study of French and British decolonisation" in P. Gifford \& W.R. Louis, eds, The Transfer of Power in Africa. Decolonisation 1940-60. Yale Univ. Press.

[56] SURET-CANALE, J., 1971. "French Colonialism in Tropical Africa, 1900-1945". Translated from French by TILL GOTTHEINER. Pica Pres, Universe Books, New York.

[57] THORN, GARY, 2000. "End of Empires: European Decolonisation 1919-80". Hodder \& Stoughton.

[58] WALLERSTEIN, I. M., 1959. "The Emergence of Two West African Nations: Ghana and the Ivory Coast". Columbia Univ. Press, New York.

[59] WIESCHHOFF, H.A., 1944. "Colonial Policies in Africa". University of Pennsylvania Press, Philadelphia.

[60] WILSON, H.S., 1994. "African Decolonisation". Edward Arnold Publishers, London. 